\title{
A novel antifungal protein from seeds of Sesbania virgata (Cav.) Pers. (Leguminosae-Faboideae)
}

\author{
Praxedes, PG., Zerlin, JK., Dias, LO. and Pessoni, RAB* \\ Curso de Ciências Biológicas, Faculdade da Saúde, Universidade Metodista de São Paulo, \\ Rua Dom Jaime Barros Câmara, 1000, Planalto, CEP 09895-400, \\ São Bernardo do Campo, SP, Brasil \\ *e-mail: rosemeire.pessoni@ metodista.br
}

Received May 3, 2010 - Accepted August 20, 2010 - Distributed August 31, 2011

(With 3 figures)

\begin{abstract}
A novel antifungal protein with a molecular mass around $50 \mathrm{kDa}$ was purified from seeds of Sesbania virgata (Cav.) Pers. using ammonium sulfate fractionation followed by gel filtration on a Sephadex G-75 Superfine (Sigma) column and reverse-phase high performance liquid chromatography on a C8 column. The protein, designated FP1-A, with a novel $\mathrm{N}$-terminal sequence AMVHSPGG(S)FS(P), showed growth inhibitory activity of filamentous fungi Aspergillus niger, Cladosporium cladosporioides, Colletotrichum gloeosporioides and Fusarium solani.
\end{abstract}

Keywords: plant defence, antimicrobial protein, filamentous fungi, seed protein.

\section{Uma nova proteína antifúngica obtida de sementes de Sesbania virgata (Cav.) Pers. (Leguminosae-Faboideae)}

\begin{abstract}
Resumo
Uma nova proteína com atividade antifúngica, com massa molar de cerca de $50 \mathrm{kDa}$, foi purificada de sementes de Sesbania virgata (Cav.) Pers. utilizando precipitação com sulfato de amônia, filtração em gel em coluna de Sephadex G-75 Superfine (Sigma) e cromatografia líquida de alta eficiência em fase reversa (coluna C8). A proteína purificada foi designada FP1-A, com a sequência N-terminal AMVHSPGG(S)FS(P), apresentando atividade inibitória do crescimento dos fungos filamentosos Aspergillus niger, Cladosporium cladosporioides, Colletotrichum gloeosporioides e Fusarium solani.
\end{abstract}

Palavras-chave: mecanismo de defesa em planta, proteína antimicrobiana, fungos filamentosos, proteína de semente.

\section{Introduction}

Fungi, bacteria, viruses and nematodes continually challenge plants growing under natural environmental conditions, but few pathogens succeed in invading plant tissues. Owing to the fact that plants have different defence strategies ranging from structural barriers and pre-formed antimicrobial to adaptive defensive mechanisms that encompass non-host-race-specific and race-non-specific resistance (Gurr and Rushton, 2005), disease is rare in nature.

Although plants do not have an immune system, they have evolved a variety of potent defensive mechanisms, including the synthesis of low-molecular-weight compounds, proteins and peptides with antifungal activity. Plant antifungal proteins include enzymes such as glucanases and chitinases, which can interact with membrane components such as lipid transfer proteins (TPs), thaumatin-related proteins, defensins, glycine/histidine-rich proteins and cyclophilin-like proteins (Wang et al., 2004; Wong and
NG, 2005; Ferreira et al., 2007). The constitutive expression of plant antimicrobial proteins in the peripheral cells of seeds, flower organs, leaves and tubers is consistent with their role in the first-line defence of vulnerable tissues (Broekaert et al., 1995). This inference is strengthened by the rapid induction of certain antimicrobial peptides after plants are infected by microorganisms or injured (Hancock and Lehrer, 1998). It has also been suggested that antifungal proteins are important components of the defence system in seeds. Locating seed proteins and their release during the inhibition process can contribute to the control of seed- and soil-borne fungal diseases. Defensive proteins, therefore, enhance the chances of seedling survival and plant reproduction (Diz et al., 2003).

In legumes, seed storage proteins such as vicilins have also been considered as defensive mechanisms as they interfere with spore germination of phytopathogenic fungi 
by attaching them to cell wall polymers (Gomes et al., 1998). These seed proteins can be modified by endogenous proteinases causing the release of antifungal peptides that, together with constitutive proteins, can act as a precocious defensive system during both germination and early stages of plant development (Wang et al., 2002). Proteins having important biological activities have been detected in seeds of leguminous plants such as Pisum sativum (Almeida et al., 2000; Ye et al., 2000), Phaseolus vulgaris (Wong and $\mathrm{Ng}$, 2005), Phaseolus mungo (Wang et al., 2004; Ye and $\mathrm{Ng}, 2005$ ), Glycine max (Krishnaveni et al., 1999), Vigna unguiculata (Gomes et al., 1998; Carvalho et al., 2001), Cicer arietinum (Ye et al., 2002) and Delandia umbellata (Ye and $\mathrm{Ng}, 2002$ ).

Sesbania virgata (Cav.) Pers. is a perennial, fastgrowing shrub legume that is native to South America and popularly known as "saranzinho", "mãe-josé" or "feijãozinho" (Braggio et al., 2002). It produces a large number of seeds with long-term viability, dispersed from indehiscent legume fruits that float in water (Pott and Pott, 1994). This tropical legume has been used for revegetation of riparian forests, soil erosion control, and the rehabilitation of degraded areas (Pott and Pott, 1994) due to its rusticity and capacity for establishing symbiosis with rhizobia (Braggio et al., 2002; Araújo et al., 2004). Recently, a flavonoid (+)-catechin, with antimicrobial activity was found in high amounts in seed leachates of S. virgata (Simões et al., 2008). However, there is no information about the presence and activity of antimicrobial proteins in seeds of this species. In this work, we describe the purification of an antifungal protein isolated from seeds of $S$. virgata.

\section{Materials and Methods}

\subsection{Materials}

Seeds of Sesbania virgata (Cav.) Pers. (LeguminosaeFaboideae) were harvested on the campus of University Metodista of São Paulo, SP, Brazil. The filamentous fungi Aspergillus niger V. Tiegh (SPC 1493), Cladosporium cladosporioides (Fresen) G.A. de Vries (SPC 140), Fusarium solani (Mart.) Sacc. (SPC 980) and Colletotrichum gloeosporioides (Penzig) Saccardo (SPC 1487) were kindly provided by the Department of Mycologia, Botanical Institute of São Paulo, SP, Brazil. All chemicals were of the highest purity available.

\subsection{Sample preparation}

The protein purification procedure was based on that described by Almeida et al. (2000). Quiescent seeds of $S$. virgata were ground in a laboratory mill, defatted with petroleum ether $(10 \%, \mathrm{w} / \mathrm{v})$ under continuous stirring for 72 hours, and air-dried at room temperature. The defatted meal was re-suspended in $25 \mathrm{mM}$ Tris- $\mathrm{HCl}$ buffer $[1: 6$ (w/v), meal:buffer], $\mathrm{pH} 7.5$, containing $100 \mu \mathrm{g} \cdot \mathrm{mL}^{-1}$ of PMSF (phenylmethylsulfonyl fluoride) and stirred for 4 hours at $4{ }^{\circ} \mathrm{C}$. The suspension was centrifuged at
$13,000 \mathrm{~g}$ for 30 minutes. The supernatant is referred to as the crude extract.

\subsection{Isolation: ammonium sulphate precipitation}

The crude extract was first fractionated at $4{ }^{\circ} \mathrm{C}$ by adding ammonium sulphate to $35 \%, 65 \%$, and $85 \%$ of saturation. The individual precipitated fractions were collected by centrifugation at $12,000 \mathrm{~g}$ for 30 minutes, and then they were dissolved in a small amount of buffer.

\subsection{Sephadex ${ }^{\mathrm{TM}}$ G75 gel filtration}

The fractions with antifungal activity were subjected to gel filtration on a Sephadex ${ }^{\mathrm{TM}} \mathrm{G}-75$ Superfine (Sigma) column $(1.5 \times 100 \mathrm{~cm})$ at a flow rate of $0.7 \mathrm{~mL} \cdot \mathrm{min}^{-1}$, using $25 \mathrm{mM}$ Tris-HCl, pH 7.5 to estimate the molecular weight. The column was calibrated with cytochrome c (12.5 kDa), carbonic anhydrase $(29 \mathrm{kDa})$, ovoalbumin $(45.0 \mathrm{kDa})$, and bovine serum albumin $(66.0 \mathrm{kDa})$. The void volume (Vo) was determined with Blue Dextran (2,000 kDa). Using a Bio-Rad protein assay kit and BSA as a standard, optical densities (DO) of eluted fractions $(1.5 \mathrm{~mL})$ were measured at $280 \mathrm{~nm}$ and protein concentrations were determined as by Bradford (1976).

\subsection{High-performance liquid chromatography (HPLC)}

Fractions containing antifungal activity were pooled, centrifuged at $11,000 \mathrm{G}$ for 5 minutes, and further purified by reverse-phase HPLC on a $\mathrm{C}_{8}$ column (Varian) using buffer A $(0.1 \%$ TFA) and buffer B $(0.1 \%$ TFA plus $90 \%$ acetronitrile) as eluants. The flow rate was $0.7 \mathrm{~mL} \cdot \mathrm{min}^{-1}$ and the absorbances of the fractions were measured at $214 \mathrm{~nm}$. Samples of a $1 \mathrm{~mL}$ volume were collected.

\subsection{Polyacrylamide gel electrophoresis}

SDS-PAGE (Sodium dodecyl sulphate-polyacrylamide gel electrophoresis) was carried out on $0.75 \mathrm{~mm}$ thick slab gels containing a $12 \%$ gradient of acrylamide with a stacking gel of $4 \%$ acrylamide in the Laemmli system (Laemmli, 1970). Gels were stained with Coomassie Blue R 250 (Bio-Rad). Molecular mass standards were myosin (216 kDa), $\beta$-galactosidase (132 kDa), bovine serum albumin $(78 \mathrm{kDa})$, carbonic anhydrase $(45.7 \mathrm{kDa})$, trypsin inhibitor (32.5 kDa), lysozyme (18.4 kDa) and aprotinin (7.6 kDa) (Kaleidoscope Prestained Standards, Bio-Rad).

\subsection{Amino acid sequence analysis}

The amino acid sequencing of the purified protein obtained from HPLC was performed by Edman degradation using a protein sequencer, model PPSQ-23 (Shimadzu Corporation).

\subsection{Assay of antifungal activity}

Antifungal activity was determined by a radial growthinhibition assay using filamentous fungi. Samples (1 mL) of the crude extract or the purified fractions were added separately to $10 \mathrm{~mL}$ of SDA medium at $45^{\circ} \mathrm{C}$, rapidly mixed and poured into individual small Petri plates. After the agar cooled down, a small amount of mycelia was added to the centre of each plate. A buffer without any 
antifungal protein was used as a control. After incubation at $25^{\circ} \mathrm{C}$ for 72 hours, the area of the mycelial colony was measured and the percentages of inhibition of growth relative to the controls were calculated (Wong and $\mathrm{Ng}$, 2005). The Tris- $\mathrm{HCl}$ buffer, $\mathrm{pH} 7.5$ was used as a control. Statistical analysis of the data obtained in the present study was carried out in a completely randomized design layout with three replicates using PAST (Hammer et al., 2001). Where a significant difference between means was observed based on ANOVA, the comparison of means of different treatments was performed using Tukey's test at $\mathrm{p}<0.05$.

\section{Results}

The starting material for the isolation of the S. virgata antifungal protein was the crude extract $(25 \mathrm{mM}$ Tris- $\mathrm{HCl}$, $\mathrm{pH}$ 7.5) obtained from the defatted mature seeds. During the purification process, almost all the antifungal activity could be recovered in the $35-65 \%$ ammonium sulphate precipitate (P65\%, data not shown). Purification of $\mathrm{P} 65 \%$ was performed by gel filtration column chromatography on Sephadex ${ }^{\text {TM }}$ G-75 Superfine column and the eluted fractions were monitored for their ability to inhibit the radial growth of $A$. niger, as well as their OD at $280 \mathrm{~nm}$. Gel filtration resolved the mixture into two main fractions. F1 and F2 with antifungal activity (Figure 1).

The molecular masses of these fractions were estimated by gel filtration chromatography (Table 1). Further purification of F1 and F2 was done by using reverse-phase high-performance liquid chromatography (RP-HPLC) (Figure 2). Only one peak was detected in F1, called F1-A (Figure 2a), and it produced a single band with a molecular mass of $50 \mathrm{kDa}$ in SDS-polyacrylamide gel electrophoresis



- Monitored at $280 \mathrm{~nm} \quad \circ$ Aspergillus niger

Figure 1. Gel filtration profile of the $35-65 \%$ ammonium sulphate precipitate (P65\%). The sample was dissolved in 25 mM Tris-HCl, pH 7.5 and applied on a Sephadex ${ }^{\mathrm{TM}} \mathrm{G}-75$ Superfine column at a flow rate of $0.35 \mathrm{~mL} / \mathrm{min}$. The absorbances of the fractions collected $(1.5 \mathrm{~mL})$ were monitored at $280 \mathrm{~nm}(\bullet)$. Antifungal activity was determined by a radial growth-inhibition assay with Aspergillus niger $(\mathrm{O})$. The column was calibrated with cytochrome c (12.5 kDa), carbonic anhydrase $(29 \mathrm{kDa})$, ovoalbumin $(45.0 \mathrm{kDa})$, and bovine serum albumin $(66.0 \mathrm{kDa})$. The void volume $(\mathrm{Vo})$ was determined with Blue Dextran (2,000 kDa).
(Figure 3 ) in agreement with the molecular mass estimated for the gel filtration column. The F2 fraction was not purified (Figure 2b).

F1-A was lyophilized and sequenced. The N-terminal amino acid sequence of the protein was determined to be AMVHSPGG(S)FS(P) by Edman degradation. This $\mathrm{N}$-terminal amino acid sequence was not identical to that of any other proteins in the database, indicating that F1-A was a novel antifungal protein.

The partially purified proteins from $S$. virgata obtained by gel filtration chromatography (F1 and F2) induced growth inhibition of A. niger, C. cladosporioides and

Table 1. The concentrations of protein and the molecular mass of the fractions F1 and F2 as estimated by gel filtration chromatography (Sephadex ${ }^{\text {TM }}$ G-75).

\begin{tabular}{lrc}
\hline \multicolumn{1}{c}{ Fraction } & $\begin{array}{c}\text { Protein } \\
(\mu \mathbf{g} / \mathbf{m L})\end{array}$ & $\begin{array}{c}\text { Molecular mass } \\
(\mathbf{k D a})\end{array}$ \\
\hline Crude extract & 1210.0 & - \\
P65\% & 900.0 & - \\
F1 & 28.2 & 25 to 50 \\
F2 & 12.4 & 4 to 8 \\
\hline
\end{tabular}
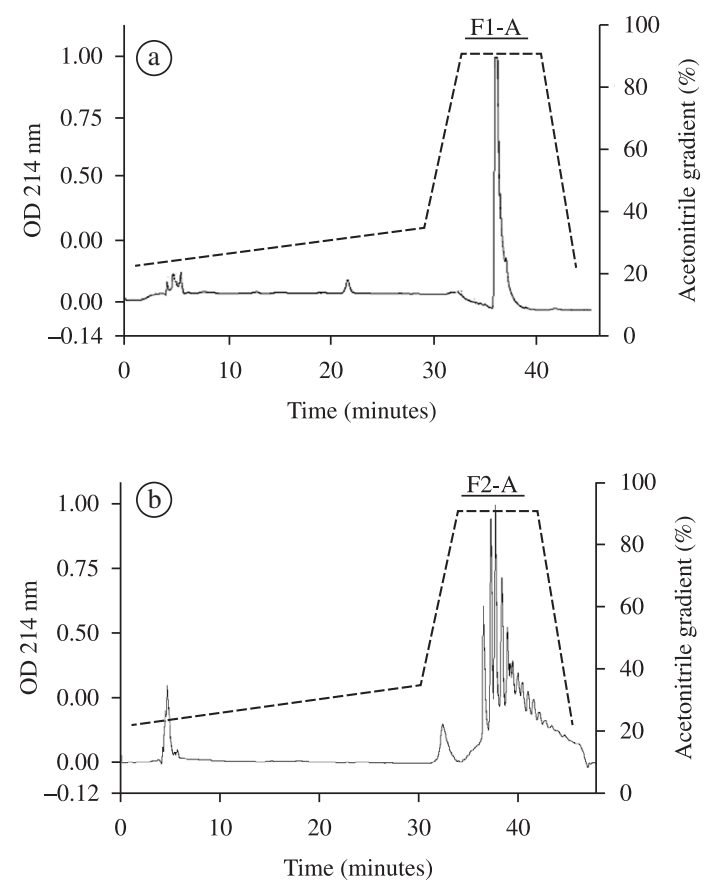

Figure 2. Reverse-phase high-performance liquid chromatography (RP-HPLC) of fractions obtained from the gel filtration column shown in Figure 1. A= Fraction $1(\mathrm{~F} 1)$; $\mathrm{B}=$ Fraction 2 (F2). C-8 column (Varian) equilibrated with $0.1 \%$ TFA and $22.5 \%$ acetonitrile was used. The retained proteins were eluted at a flow rate of $0.7 \mathrm{~mL} / \mathrm{min}$ using a linear acetonitrile gradient $(22.5-35 \%, \mathrm{v} / \mathrm{v}$, in $0.1 \%$ TFA) followed by $90 \%$ acetonitrile/0.1\% TFA (---). The protein content was determined by the measurement of the OD at $214 \mathrm{~nm}(-)$. 
Table 2. Effect of different fractions of Sesbania virgata seeds on the growth of filamentous fungi. Fraction F1 and F2 were obtained from the Sephadex ${ }^{\mathrm{TM}} \mathrm{G}-75$ column.

\begin{tabular}{|c|c|c|c|c|c|c|c|c|}
\hline \multirow[t]{2}{*}{ Sample } & \multicolumn{2}{|c|}{$\begin{array}{c}\text { Aspergillus } \\
\text { niger }\end{array}$} & \multicolumn{2}{|c|}{$\begin{array}{l}\text { Cladosporium } \\
\text { cladosporioides }\end{array}$} & \multicolumn{2}{|c|}{$\begin{array}{l}\text { Colletrotrichum } \\
\text { gloesoporioides }\end{array}$} & \multicolumn{2}{|c|}{$\begin{array}{c}\text { Fusarium } \\
\text { solani }\end{array}$} \\
\hline & $\mathrm{RG}^{1}(\mathrm{~cm})$ & $\operatorname{RGI}^{2}(\%)$ & $\mathrm{RG}^{1}(\mathrm{~cm})$ & $\operatorname{RGI}^{2}(\%)$ & $\mathrm{RG}^{1}(\mathrm{~cm})$ & $\operatorname{RGI}^{2}(\%)$ & $\mathrm{RG}^{1}(\mathrm{~cm})$ & $\operatorname{RGI}^{2}(\%)$ \\
\hline Control & $4.7^{\mathrm{a}}$ & - & $3.4^{\mathrm{a}}$ & - & $2.6^{\mathrm{a}}$ & - & $3.2^{\mathrm{a}}$ & - \\
\hline $\mathrm{F} 1$ & $2.7^{\mathrm{b}}$ & 42 & $2.3^{\mathrm{b}}$ & 30 & $1.9^{\mathrm{b}}$ & 29 & $2.5^{\mathrm{b}}$ & 23 \\
\hline $\mathrm{F} 2$ & $2.9^{\mathrm{b}}$ & 38 & $2.1^{\mathrm{b}}$ & 35 & $1.8^{\mathrm{b}}$ & 30 & $2.8^{\mathrm{a}}$ & 12 \\
\hline
\end{tabular}

${ }^{1}$ Radial growth (RG). Tests were performed in triplicates for each microorganism evaluated and results presented as arithmetic average. ${ }^{2}$ Radial growth inhibition (RGI). Results expressed in percentage of radial growth inhibition in comparison with the control assay. In each column, means followed by different letters are significantly different $(\mathrm{p}<0.05)$.

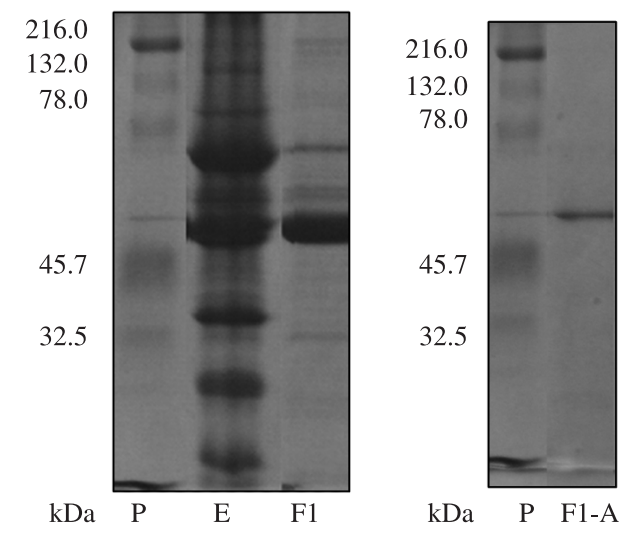

Figure 3. Polyacrylamide gel electrophoresis of $S$. virgata proteins. Lane 1, molecular mass markers; lane 2, crude extract; lane 3, F1 sample from Sephadex ${ }^{\mathrm{TM}}$ G-75 column. Molecular mass standards were myosin $(216 \mathrm{kDa}), \beta$-galactosidase $(132 \mathrm{kDa})$, bovine serum albumin $(78 \mathrm{kDa})$, carbonic anhydrase $(45,7 \mathrm{kDa})$, and trypsin inhibitor (32.5 kDa) (Kaleidoscope Prestained Standards, Bio-Rad).

C. gloesoporioides (35-40\%) and reduced sporulation of A. niger and C. cladosporioides (data not shown). The nature of the inhibition of fungal growth was distinct among species, probably due to differences in fungal sensitivity (Table 2). When C. gloesoporioides and Fusarium solani were incubated with F1-A $\left(2 \mu \mathrm{g} \cdot \mathrm{mL}^{-1}\right)$, no inhibitory growth was observed for 3 days.

\section{Discussion}

The present investigation represents the first reported endeavour to chromatographically isolate an antifungal protein from seeds of $S$. virgata. The purification scheme used for isolating the F1-A antifungal protein is simple and convenient as only gel filtration column chromatography and reverse-phase HPLC are involved. It required fewer steps than protocols previously used for purifying other antifungal proteins (Almeida et al. 2000).

Antifungal proteins and peptides with molecular masses ranging from 5 to $38 \mathrm{kDa}$ were isolated from legume seeds (Ye et al., 2000; Ye and Ng, 2002, 2005; Park et al., 2009).
Despite the higher molecular mass $(50 \mathrm{kDa}), \mathrm{F} 1-\mathrm{A}$ represents another antifungal protein purified from a legume seed and its partial sequence similarity with other defensive proteins suggests that it is a novel protein.

The growth of the assayed fungi was inhibited up to $30 \%$ during the treatment with the isolated protein from seeds of $S$. virgata, using concentrations ranging from 12.4 to $28.2 \mathrm{mg} \cdot \mathrm{mL}^{-1}$. A similar range of antifungal activity compared to various fungi was ascribed to other antifungal proteins at concentrations from 0.5 to $25 \mathrm{mg} \cdot \mathrm{mL}^{-1}$ (Osborn et al., 1995; Almeida et al., 2000). Differences in the growth-inhibitory activity of F1 and F2 on the assayed fungal species were probably due to differences in fungal sensitivity, which has been reported for other proteins (Ye et al., 2000). However, after purification on the C-8 reversed phase column, no activity was found among fractions. It is possible that the protein did not assemble properly at low protein concentration $\left(\mu \mathrm{g} \cdot \mathrm{mL}^{-1}\right)$. According to Wang and Bunkers (2000), the lack of activity of isolated proteins could be explained by the need of other proteins or subunits to keep antimicrobial activity, which can be lost during the stage of purification. It is believed that in plants, multiple proteins antimicrobial activity are used in defense against pathogens that plants will encounter in their environment. There is an obvious advantage of using multiple proteins for pathogen control. Since different proteins antimicrobial activity might use different mechanisms in their antifungal action, the probability for a pathogen to develop resistance to multiple antifungal mechanisms is greatly diminished (Kim et al., 2009; Park et al., 2009).

The molecular mechanism of the antifungal activity of F1-A was not investigated but information regarding the three-dimensional structure of this protein, which was isolated from $S$. virgata seeds may be helpful in elucidating this question. Although drugs such as polyenes, azole derivatives and fluorinated pyrimidines are presently used for treating fungal infections, a new threat has emerged due to the appearance of fungal strains resistant to these drugs. Thus, the discovery of new antifungal proteins opens up the possibilities to use natural agents to effectively control fungal diseases (Wong and $\mathrm{Ng}$, 2005). Our study 
suggests that $S$. virgata might be a good source to isolate novel antimicrobial proteins.

Acknowledgments - We would like to thank Dr. Isaura Yoshico Hirata (Biophysics Division, UNIFESP, Brazil) for the amino acid sequence analysis and Dr. Candida C. Jesus Vieira (Methodist University of São Paulo/UMESP) for the critical review of this manuscript. This work was supported by the State of São Paulo Research Foundation (FAPESP, grant 04/079221). LOD was a recipient of a fellowship from CNPq (IC).

\section{References}

ALMEIDA, MS., CABRAL, KMS., ZINGALI, RB. and KURTENBACH, E., 2000. Characterization of two novel defense peptides from pea (Pisum sativum) seeds. Archives of Biochemistry and Biophysics, vol. 378, p. 278-286. PMid:10860545. http:// dx.doi.org/10.1006/abbi.2000.1824

ARAÚJO, EC., MENDONÇA, AVR., BARROSO, DG, LAMÔNICA, KR. and SILVA, RF., 2004. Caracterização morfológica de frutos, sementes e plântulas de Sesbania virgata (CAV.) PERS. Revista Brasileira Sementes, vol. 26, p. 105-110.

BRADFORD, MM., 1976. A rapid and sensitive method for the quantitation of microgram quantities of protein utilizing the principle of protein-dye binding. Analytical Biochemistry, vol. 2, p. 248-254.

BRAGGIO, MM., LIMA, MEL., VEASEY, EA. and HARAGUCHI, M., 2002. Atividades farmacológicas das folhas da Sesbania virgata (Cav.) Pers. Arquivos do Instituto Biológico São Paulo, vol. 69 , p. 49-53.

BROEKAERT, WF., TERRAS, FR., CAMMUE, BP. and OSBORN, RW., 1995. Plant defensions, novel antimicrobial peptides as components of the host defense system. Plant Physiology, vol. 108, p.1353-1358. PMid:7659744. PMCid:157512. http:// dx.doi.org/10.1104/pp.108.4.1353

CARVALHO, AO., MACHADO, OLT., CUNHA, M., SANTOS, IS. and GOMES, VM., 2001. Antimicrobial peptides and immunolocalization of a LTP in Vigna unguiculata seeds. Plant Physiology Biochemistry, vol. 39, p. 137-146. http://dx.doi. org/10.1016/S0981-9428(00)01230-4

DIZ, MSS., CARVALHO, AO. and GOMES, V., 2003. Purification and molecular mass determination of a lipid transfer protein exuded from Vigna unguiculata seeds. Brazilian Journal Plant Physiology, vol. 15, p. 171-175.

FERREIRA, RB., MONTEIRO, S., FREITAS, R., SANTOS, CN., CHEN, Z., BATISTA, LM., DUARTE, J., BORGES, A. and TEIXEIRA, AR., 2007. The role of plant defence proteins in fungal pathogenesis. Molecular Plant Pathology, vol. 8, p. 1-24.

GOMES, VM., CUNHA, MD., MIGUENS, FC., FERNANDES, KVS., ROSE, TL. and XAVIER-FILHO, J., 1998. Ultrastructure and immonolabelling of fungi cells treated with Vigna unguiculata vicilins, 7S storage proteins. Plant Science, vol. 138, p. 81-89. http://dx.doi.org/10.1016/S0168-9452(98)00148-4

GURR, SJ. and RUSHTON, PJ., 2005. Engineering plants with increased disease resistance, what are we going to express? Trends in Biotechnology, vol. 23, p. 275-282. PMid:15922079. http:// dx.doi.org/10.1016/j.tibtech.2005.04.007
HAMMER, O., HARPER, DAT. and RYAN, PD., 2001. PAST: Paleontological Statistics Software Package for Education and Data Analysis. Palaeontologia Electronica, vol. 4, no. 1, p. 9.

HANCOCK, REW. and LEHRER, RI., 1998. Cationic peptides, a new source of antibiotics. Trends in Biotechnology, vol. 16, p. 82-88. http://dx.doi.org/10.1016/S0167-7799(97)01156-6

KIM, JY., PARK, SC., HWANG, I., CHEONG, H., NAH, JW., HAHM, KS. and PARK, Y., 2009. Protease inhibitors from plants with antimicrobial activity. International Journal of Molecular Sciences, vol. 10, p. 2860-2872. PMid:19582234. PMCid:2705521. http://dx.doi.org/10.3390/ijms10062860

KRISHNAVENI, S., LIANG, GH., MUTHUKRISHNAN, S. and MANICKAM, A., 1999. Purification and partial characterization of chitinases from sorghum seeds. Plant Science, vol. 144, p. 1-7. http://dx.doi.org/10.1016/S0168-9452(99)00050-3

LAEMMLI, UK., 1970. Cleavage of structural proteins during the assembly of the head of bacteriophage T4. Nature, vol. 227, p. 680-685.

OSBORN, WR., SAMBLANX, GW., TREVISSEN, K., GODERIS, I., TORREKENS, S., VAN LEUVEN, F., ATTENBOROUGH, S., REES, SB. and BROEKAERT, WF., 1995. Isolation and characterization of plant defensins from seeds Asteraceae, Fabaceae, Hippocastanaceae and Saxifragaceae. FEBS Letters, vol. 368, p. 257-262. http://dx.doi.org/10.1016/0014-5793(95)00666-W

PARK, SC., KIM, JY., LEE, JK., HWANG, I., CHEONG, H., NAH, JW., HAHM, KS. and PARK, YY., 2009. Antifungal mechanism of a novel antifungal protein from Pumpkin rinds against various fungal pathogens. Journal of Agricultural and Food Chemistry, vol. 57, p. 9299-9304. PMid:19807165. http:// dx.doi.org/10.1021/jf902005g

POTT, A. and POTT, VJ., 1994. Plantas do pantanal. Brasília: Embrapa/CPAP/SPI. p. 320.

SIMÕES, K., DU, J., KRETZSCHMAR, FS., BROECKLING, CD., STERMITZ, F., VIVANCO, JM. and BRAGA, MR., 2008. Phytotoxic catechin leached by seeds of the tropical weed Sesbania virgata. Journal of Chemical Ecology, vol. 34, p. 681-687. PMid:18427901. http://dx.doi.org/10.1007/s10886-008-9443-1

WANG, X. and BUNKERS, GJ., 2000. Potent heterologous antifungal proteins from Cheeseweed (Malva parviflora). Biochemical and Biophysical Research Communications, vol. 279, p. 669-673. http://dx.doi.org/10.1006/bbrc.2000.3997

WANG, X., THOMA, RS., CARROL, JA. and DUFFIN, KL., 2002. Temporal generation of multiple antifungal proteins in primed seeds. Biochemical and Biophysical Research Communications, vol. 292, p. 236-242. PMid:11890698. http://dx.doi.org/10.1006/ bbrc. 2002.6637

WANG, SY., WU, JH., NG, TB., YE, XY. and RAO, PF., 2004. A non-specific lipid transfer protein with antifungal and antibacterial activities from the mung bean. Peptides, vol. 25, p. 1235-1242. PMid:15350690. http://dx.doi.org/10.1016/j.peptides.2004.06.004

WONG, JH. and NG, TB., 2005. Sesquin, a potent defensinlike antimicrobial peptide from ground beans with inhibitory activities toward tumor cells and HIV-1 reverse transcriptase. Peptides, vol. 26, p. 1120-1126. PMid:15949629. http://dx.doi. org/10.1016/j.peptides.2005.01.003 
-, 2005. Vulgarinin, a broad spectrum antifungal peptide from haricot beans (Phaseolus vulgaris). Int J Biochem Cell Biol., vol. 37, p. 1626-1632

YE, X.Y., NG, T.B., RAO PF. (2002a). Cicerin and arietin, novel chickpea peptides, with different antifungal potencies. Peptides, vol. 23, p. 817-822
YE, XY. and NG, TB., 2002. Delandin, a chitinase-like protein with antifungal, HIV-1 reverse transcriptase inhibitory and mitogenic activities from the rice bean Delandia umbellate. Protein Expression and Purification, vol. 24, p. 524-529. PMid:11922770. http://dx.doi.org/10.1006/prep.2001.1596

-, 2005. A chitinase with antifungal activity from the mung bean. Protein Expression and Purification, vol. 40, p. 230-236. PMid:15766863. http://dx.doi.org/10.1016/j.pep.2004.06.032

YE, XY., WANG, HX. and NG, TB., 2000. Sativin, a novel antifungal miraculin-like protein isolated from legumes of the sugar snap Pisum sativum var. macrocarpon. Life Sciences, vol. 67, p. 775-781. http://dx.doi.org/10.1016/S0024-3205(00)00672-X 